\title{
Administration of hydro-alcoholic extract of spinach improves oxidative stress and inflammation in high-fat diet-induced NAFLD rats
}

\section{Ali Amirinejad}

Iran University of Medical Sciences

\section{Ali Saneei Totmaj}

Iran University of Medical Sciences

Farzaneh Mardali

Iran University of Medical Sciences

\section{Azita Hekmatdoost}

Shahid Beheshti University of Medical Sciences

\section{Hadi Emamat}

Shahid Beheshti University of Medical Sciences

\section{Majid Safa}

Iran University of Medical

\section{Farzad Shidfar ( $\nabla$ shidfar.f@iums.ac.ir)}

Iran University of Medical Sciences

\section{Research Article}

Keywords: Spinach, NAFLD, inflammation, oxidative stress, PPAR-y

Posted Date: May 12th, 2021

DOl: https://doi.org/10.21203/rs.3.rs-492861/v1

License: (c) (i) This work is licensed under a Creative Commons Attribution 4.0 International License.

Read Full License 


\section{Administration of hydro-alcoholic extract of spinach improves oxidative stress and inflammation in high-fat diet-induced NAFLD rats}

Ali Amirinejad ${ }^{1}$, Ali Saneei Totmaj ${ }^{1}$, Farzaneh Mardali ${ }^{1}$, Azita Hekmatdoost ${ }^{2}$, Hadi Emamat ${ }^{3}$, Majid Safa ${ }^{4}$, Farzad Shidfar ${ }^{*}$

${ }^{1}$ Department of Nutrition, School of Public Health, Iran University of Medical Sciences, Tehran, Iran

2 Department of Clinical Nutrition and Dietetics, Faculty of Nutrition and Food Technology, National Nutrition and Food Technology, Research Institute, Shahid Beheshti University of Medical Sciences, Tehran, Iran

3 Student Research Committee, Department of Clinical Nutrition and Dietetics, Faculty of Nutrition and Food Technology, National Nutrition and Food Technology Research Institute, Shahid Beheshti University of Medical Sciences, Tehran, Iran

${ }^{4}$ Cellular and Molecular Research Center, Faculty of Allied Medicine, Iran University of Medical Sciences, Tehran, Iran

\section{Corresponding Author:}

Farzad Shidfar, Professor of Nutrition Science

School of Public Health, Iran University of Medical Sciences, Tehran, Iran

Cell: +989123082922

Postal address: 1449614535

E-mail: $\underline{\text { shidfar.f@iums.ac.ir }}$

farzadshidfar@yahoo.com

Short running title: spinach and NAFLD 


\section{Abstract}

Background Nonalcoholic fatty liver disease (NAFLD) is the most common liver disease worldwide. The aim of this study was to evaluate the effects of hydro-alcoholic extract of spinach (HES) on hepatic and serum measurements of NAFLD in a rat model.

Methods During the prevention phase, 18 Sprague-Dawley rats were fed one of the following regimens: a high-fat diet, a high-fat diet plus $400 \mathrm{mg} / \mathrm{kg}$ HES, or a chow diet ad libitum for seven weeks. Before the treatment phase, NAFLD was induced in 24 rats. Afterwards, they were fed one of the following regimens: the same NAFLD-inducing diet, high-fat diet plus 400mg/kg HES, the chow diet, or chow diet plus 400mg/kg HES ad libitum for four weeks ( $\mathrm{n}=6$ in each group).

Results Administration of HES combined with HF diet in rats was associated with decreased food intake $(\mathrm{P}<0.01)$, weight loss $(\mathrm{P}=0.01)$, and increased SOD $(\mathrm{P}=0.02)$ enzyme activity in the liver at the end of the prevention phase. hs-CRP $(\mathrm{P}<0.05), \mathrm{PTX}-3(\mathrm{P}<0.05), \mathrm{PPAR}-\gamma$, and TNF- $\alpha$ gene expression in the liver were improved by spinach intake $(\mathrm{P}<0.05)$, both in the prevention and treatment phases. Furthermore, administration of spinach in the treatment phase increased serum TAC $(\mathrm{P}=0.03)$ and hepatic GPX ( $\mathrm{P}=0.01)$ enzyme activity.

Conclusion Taking into account beneficial effects of HES on prevention and treatment of NAFLD observed in the present study, we propose that further human-based clinical investigations be conducted on subjects with NAFLD.

Key words: Spinach; NAFLD; inflammation; oxidative stress; PPAR- $\gamma$

\section{Introduction}

Nonalcoholic fatty liver disease (NAFLD) is the most common liver disease worldwide (1). NAFLD is generally defined as the hepatic accumulation of triglycerides (steatosis) which affects 
at least $5 \%$ of the liver volume or weight, in the absence of consuming significant amounts of alcohol (less than 30g/day for men and less than 20g/day for women) as well as other causes of steatosis, such as exposure to certain drugs or toxins $(2,3)$. Nonalcoholic steatohepatitis (NASH) is an advanced form of NAFLD characterized by inflammation, apoptosis, and ballooning degeneration (4). NAFLD is a multifactorial disease caused by various genetic and lifestyle interactions. Obesity, insulin resistance, diabetes, hyperlipidemia, and metabolic syndrome are the main risk factors for NAFLD $(5,6)$. Lifestyle modifications, including dietary interventions and physical activity, are the major components of medical management in $\operatorname{NAFLD}(7,8)$. Bariatric surgery is an alternative method for those who fail to attain a significant weight loss (9). Additionally, medications counteracting insulin resistance, lipid-lowering, and anti-blood pressure agents have been already used in the management of NAFLD (10).

Spinach (Spinacia Oleracea L.) is a leafy green vegetable belonging to the Amaranthaceae family. Numerous bioactive ingredients, such as $\beta$-carotene, flavonoids, phenolic compounds, lutein, lycopene, linolenic acid, and thylakoids are present in spinach $(11,12)$. These phytochemicals have been postulated to be responsible for hypoglycemic, hypolipidemic, anti-obesity, antioxidant, and anti-inflammatory properties of spinach (13). Thylakoids, major constituents of the chloroplast membranes, delay fat digestion by inhibiting pancreatic lipase/colipase $(14,15)$, leading to an increase in circulating levels of satiety hormones, including cholecystokinin (CCK). Elevated serum levels of CCK after a thylakoid-rich meal have been reported in several studies (16-19). In one study, thylakoid intake decreased fat accumulation in the liver by increasing the gene expression of the peroxisome proliferator-activated receptor gamma (PPAR- $\gamma$ ) in adipose tissue (20). 
Among extracellular matrix proteins, increased gene expression and plasma levels of matrix metalloproteinase 9 (MMP-9) have been observed in alcoholic patients, individuals with viral cirrhosis, and especially NASH $(21,22)$. A pro-inflammatory profile, including high levels of sensitive C-reactive protein (hs-CRP), pentraxin 3 (PTX-3), and tumor necrosis factor-alpha (TNF$\alpha$ ), has been observed in people with NAFLD (23-25). On the other hand, interleukin-10 (IL-10), a potent anti-inflammatory cytokine, has been shown to be inversely associated with hepatic inflammation $(26,27)$.

Consumption of spinach decreased liver steatosis and improved glucose and lipid profile in previous animal-based NAFLD models $(28,29)$. To further establish the existing data, this study aimed to investigate the effect of supplementation with hydro-alcoholic extract of spinach (HES) on serum levels and hepatic gene expression of some inflammatory and oxidative factors in a rat model of NAFLD.

\section{Materials and methods}

\subsection{Preparation of high-fat diet and spinach extract}

The high-fat, high-sugar diet was prepared by mixing butter, chow (Behparvar, Tehran, Iran) sugar, and egg; using the method previously established by Emamat et al (30). The food was given every other day at the beginning of the dark phase, and the remains were measured and removed after 48 hours.

Spinach (Spinacia oleracea) was collected from a farm in Tehran province. A plant specimen identified and kept at the herbarium of the Institute of Medicinal Plants (ACECR) Karaj, Iran with herbarium number 1325(MPIH). 
The leaves of spinach were washed and dehydrated under shaded circumstances, and then they were ground to obtain a dried powder. For preparing HES, this powder was immersed in a mixture of methanol/water (70:30, v/v) for 24 hours and it was then filtered. This procedure was replicated two more times and then the extract was concentrated in a rotary evaporator at $50^{\circ} \mathrm{C}$. The dried extract was stored in the freezer for distant use. The extraction yield of HES from leaves was 10.4 $\% \mathrm{w} / \mathrm{w}$.

\subsection{Animals and experimental method}

Forty-two male Sprague-Dawley rats aged 8 weeks (weighing $150 \pm 10 \mathrm{~g}$ ) were purchased from Pasteur Institute (Karaj, Iran) and were housed separately in polycarbonate wire cages in a standard environment $\left(20-22{ }^{\circ} \mathrm{C}, 50 \%\right.$ humidity and 12 -h light/dark cycles). After one-week acclimation, the prevention phase was designed for seven weeks and 18 rats were randomly divided into three groups ( $\mathrm{n}=6$ in each group): the first group (PC) were fed a standard chow diet with $1 \mathrm{ml}$ normal saline administered by gavage, the second group (PF) were fed a high-fat diet with $1 \mathrm{ml}$ normal saline by gavage, and the third group (PFS) received a high-fat diet with $400 \mathrm{mg} / \mathrm{kg}$ HES (1ml) by gavage for seven weeks.

In the treatment phase, 24 rats were fed the HF diet for seven weeks in order to induce NAFLD (30), and then they were randomly divided into four groups( $\mathrm{n}=6$ in each group):The first group (TC) were fed a standard chow diet with $1 \mathrm{ml}$ normal saline by gavage, the second group (TCS) were fed a standard chow diet with 400mg/kg HES (ml) by gavage, the third group received a HF diet with $1 \mathrm{ml}$ normal saline by gavage (TF), and finally the fourth group (TFS) received a HF diet with $400 \mathrm{mg} / \mathrm{kg}$ HES ( $1 \mathrm{ml}$ ) by gavage for 4 weeks. Random numbers were generated using online random number generators. The dosage of $400 \mathrm{mg} / \mathrm{kg}$ was based on the two studies by Panda et al. which reported the benefits of 14 and 45 days supplementation with HES $(400 \mathrm{mg} / \mathrm{kg})(31,32)$. 
Body weights and food intakes were registered as grams every two weeks and twice a week, respectively. At the end of the intervention, the rats were terminated by cardiac puncture under anesthesia using ketamine and xylazine. The animals had free access to food and water in all stages. All animal procedures were carried out in accordance with the Iran University of Medicals Sciences ethics committee (IR.IUMS.REC) and the study protocol was approved by IR.IUMS.REC with ethics code of IR.IUMS.REC 1396.9511468001.

\subsection{Blood and Tissue preparation}

$5 \mathrm{ml}$ blood was obtained by cardiac puncture and centrifuged $\left(2000 \mathrm{~g}, 10 \mathrm{~min}, 4{ }^{\circ} \mathrm{C}\right)$ for the clot to be removed. The supernatants were collected for biochemical analysis.

Two samples were obtained from each liver. $300 \mathrm{mg}$ tissue was excised from liver and homogenized in 3ml phosphate-buffered saline $(\mathrm{PBS}=100 \mathrm{mM}, \mathrm{pH} 7.4)$. After centrifuging (2000g, $20 \mathrm{~min}, 4^{\circ} \mathrm{C}$ ), the supernatants were collected and stored at $-80{ }^{\circ} \mathrm{C}$ for measuring antioxidant enzymes activity. Another sample (70mg) was incised and preserved in RNA for consequent gene expression assessments.

\subsection{Biochemical measurements}

Serum total antioxidant capacity (TAC) was measured using colorimetry at the wavelength of 460$490 \mathrm{~nm}$ on based on the oxidation-reduction interactions in the sample using a commercial kit (ZellBio GmbH, Germany). Serum Matrix Metalloproteinase-9 (MMP-9), hs-CRP, Pentraxin-3 (PTX3), and Cholecystokinin (CCK) were measured by the means of the biotin double antibody sandwich technology with rat commercial enzyme-linked immunosorbent assay (ELISA) kits (ZellBio GmbH, Germany). 
Liver glutathione peroxidase (GPX) and superoxide dismutase (SOD) activity were measured by colorimetry method (420 nm) using commercial kits (ZellBio GmbH, Germany).

\subsection{RNA extraction and real-time polymerase chain reaction analysis}

Total RNA was extracted using YTzol pure RNA reagent (Yekta Tajhiz Azma, Tehran, Iran) following the manufacturer's protocol; the purity was checked by the ratio of absorbance at 260 $\mathrm{nm}$ and $280 \mathrm{~nm}$ and by using Thermo Scientific ${ }^{\mathrm{TM}}$ NanoDrop ${ }^{\mathrm{TM}}$ One Microvolume UV-Vis Spectrophotometer. cDNA synthesis kit (Yekta Tajhiz Azma, Tehran, Iran), which used random hexamer primer, was employed to synthesize complementary DNA from $2 \mu \mathrm{g}$ total RNA.

The quantitative RT-PCR was performed using Roche LightCycler ${ }^{\circledR} 96$ Real-Time PCR System and YTA SYBR Green qPCR Master Mix 2X (Yekta Tajhiz Azma, Tehran, Iran). PCR reaction system contained $1 \mu \mathrm{l}$ cDNA, $1 \mu \mathrm{l}$ of the proper forward and reverse primers, and $7.5 \mu \mathrm{l}$ SYBR Green PCR Master mixed yielding a total volume of $15 \mathrm{~mL}$. The thermal cycling conditions were: $95{ }^{\circ} \mathrm{C}$ for $3 \mathrm{~min}$ (initial denaturation); $95{ }^{\circ} \mathrm{C}$ for $10 \mathrm{~s}$ repeated in 40 cycles (denaturation), and $60{ }^{\circ} \mathrm{C}$ for $1 \mathrm{~min}$ (annealing/extension). The relative expression of target genes were normalized to expression of GAPDH and fold change was calculated using $2^{-\Delta \Delta C t}$ method (33). The specificity of the PCR products was verified by melt curve analysis. The sequences of primers used in qPCR are presented in Table $\mathbf{1}$.

Table1. The sequence of primers used for gene expression

\begin{tabular}{|c|c|}
\hline GAPDH FW & 5'-CCT GTG ACT TCA ACA GCA ACT C-3' \\
\hline GAPDH RW & 5'-GGT GGT CCA GGG TTT CTT ACT C-3' \\
\hline PPAR- $\gamma$ FW & 5'-GTT CAC AAG AGC TGA CCC AAT G-3' \\
\hline PPAR- $\gamma$ RW & 5'-TGT GGC CTG TTG TAG AGT TGG-3' \\
\hline
\end{tabular}




\begin{tabular}{|c|c|}
\hline TNF- $\alpha$ FW & 5'-CCA AAT GGG CTC CCT CTC ATC-3' \\
\hline TNF- $\alpha$ RW & 5'-CCG CTT GGT GGT TTG CTAC-3' \\
\hline IL-10 FW & 5'-GCG ACG CTG TCA TCG ATT TC-3' \\
\hline IL-10 RW & 5'-AGT GTC ACG TAG GCT TCT ATG C-3' \\
\hline
\end{tabular}

\subsection{Statistical analysis}

All results are expressed as mean \pm SD. The analysis was performed using the SPSS v.22 software (Chicago, IL, USA). The normality of data was analyzed by the means of the KolmogorovSmirnov test. Regarding the data with a normal distribution, statistical disparities between groups were assessed using the one-way ANOVA test followed by the LSD post-hoc test; the KruskalWallis test was used in the case of non-normality. $P<0.05$ was considered statistically significant for all the tests mentioned.

\section{Results}

\subsection{Prevention phase}

Total weight gain and food intake, serum levels of inflammation, oxidative stress biomarkers, and antioxidant activity in the liver are presented in the Table 2. Total weight gain and food intake were significantly greater in PF group compared to PC and PFS groups $(P<0.01)$. Additionally, serum levels of hs-CRP and PTX-3 in the PF group were significantly greater than those of PFS group after seven weeks of intervention $(P=0.01)$. The liver activity of SOD was also higher in the PFS group compared to the PF group $(P=0.02)$. No significant differences were observed in serum MMP-9, CCK, TAC, and liver activity of GPX among groups. 
Receiving HES for seven weeks significantly increased liver gene expression of PPAR- $\gamma$ when compared to other groups $(P<0.01)$. Liver gene expression of TNF- $\alpha$ was significantly higher in the PF group compared to other groups at the end of the prevention phase $(P<0.05)$. No significant changes were seen in IL-10 levels among groups (shown in Fig. 1).

Table2. Weight gain, total food intake, serum inflammation and oxidative stress biomarkers, and antioxidant enzyme activity in liver at the end of the prevention phase.

\begin{tabular}{|c|c|c|c|c|}
\hline Variables & $\begin{array}{l}\text { Control } \\
(\mathrm{n}=6)\end{array}$ & $\begin{array}{l}\text { High-fat } \\
(n=6)\end{array}$ & $\begin{array}{c}\text { High-fat }+ \text { Spinach } \\
(n=6)\end{array}$ & $\begin{array}{l}P \text { value, } \\
\text { ANOVA }\end{array}$ \\
\hline Weight gain (g) & $94 \pm 19.1^{\mathrm{a}}$ & $142.8 \pm 26^{\mathrm{b}}$ & $116.1 \pm 16.2^{\mathrm{a}}$ & $<0.01^{*}$ \\
\hline Food Intake (g) & $152.4 \pm 13.9^{\mathrm{a}}$ & $175.8 \pm 12.3^{\mathrm{b}}$ & $159.9 \pm 8.7^{\mathrm{a}}$ & $0.01^{*}$ \\
\hline CCK (ng/l) & $139.1(103-187.5)$ & $155.6(128.5-216.5)$ & $124(114.9-133.1)$ & $0.22^{\dagger}$ \\
\hline hs_CRP(ng/ml) & $3 \pm 0.5^{\mathrm{a}}$ & $4.1 \pm 0.7^{b}$ & $3.2 \pm 0.5^{\mathrm{a}}$ & $0.01^{*}$ \\
\hline PTX-3 (ng/ml) & $0.66 \pm 0.09^{\mathrm{a}}$ & $0.84 \pm 0.09^{b}$ & $0.68 \pm 0.11^{\mathrm{a}}$ & $0.01^{*}$ \\
\hline MMP-9 (ng/ml) & $0.65 \pm 0.1$ & $0.74 \pm 0.1$ & $0.62 \pm 0.1$ & 0.28 \\
\hline TAC $(\mu \mathrm{mol} / \mathrm{l})$ & $227.8 \pm 26.9$ & $220.3 \pm 16.7$ & $216.6 \pm 22.3$ & 0.68 \\
\hline GPX (U/ml) & $228.3 \pm 54.2$ & $220.8 \pm 38.8$ & $288 \pm 85$ & 0.15 \\
\hline $\operatorname{SOD}(\mathbf{U} / \mathbf{m l})$ & $54 \pm 20.7^{\mathrm{ab}}$ & $37.8 \pm 14.3^{\mathrm{a}}$ & $65.9 \pm 9.4^{b}$ & $0.02^{*}$ \\
\hline Steatosis score & $0(0-0.25)^{\mathrm{a}}$ & $2(1-2)^{b}$ & $1(0-1)^{\mathrm{a}}$ & $<0.01^{\dagger}$ \\
\hline NAS score & $0.5 \pm 0.83^{\mathrm{a}}$ & $3.83 \pm 1.16^{\mathrm{b}}$ & $2 \pm 1.09^{c}$ & $<0.001^{*}$ \\
\hline $\begin{array}{l}\text { Values are expressed a } \\
C \mathrm{CK}=\text { Cholecystokinin } \\
\Gamma A C=\text { total antioxidant } \\
\text { ifferent letters show s } \\
\text { Kruskal-Wallis test. }\end{array}$ & $\begin{array}{l}\mathrm{n} \pm \text { SD for data wit } \\
\mathrm{RP}=\text { high-sensitivit } \\
\text { city, GPX= glutathio } \\
\text { cant difference at } \mathrm{P}\end{array}$ & $\begin{array}{l}\text { al distribution and med } \\
\text { ctive protein, } \mathrm{PTX}-3= \\
\text { xidase, } \mathrm{SOD}=\text { superox }\end{array}$ & $\begin{array}{l}\text { R) for those with non } \\
\text { xin-3, MMP-9= matri } \\
\text { mutase }\end{array}$ & $\begin{array}{l}\text { distributi } \\
\text { oproteina }\end{array}$ \\
\hline
\end{tabular}


Fig. 1. Liver gene expression of PPAR- $\gamma, \mathrm{TNF}-\alpha$, and IL-10 at the end of the prevention phase.

Different letters show significant difference at $\mathrm{P}<0$.
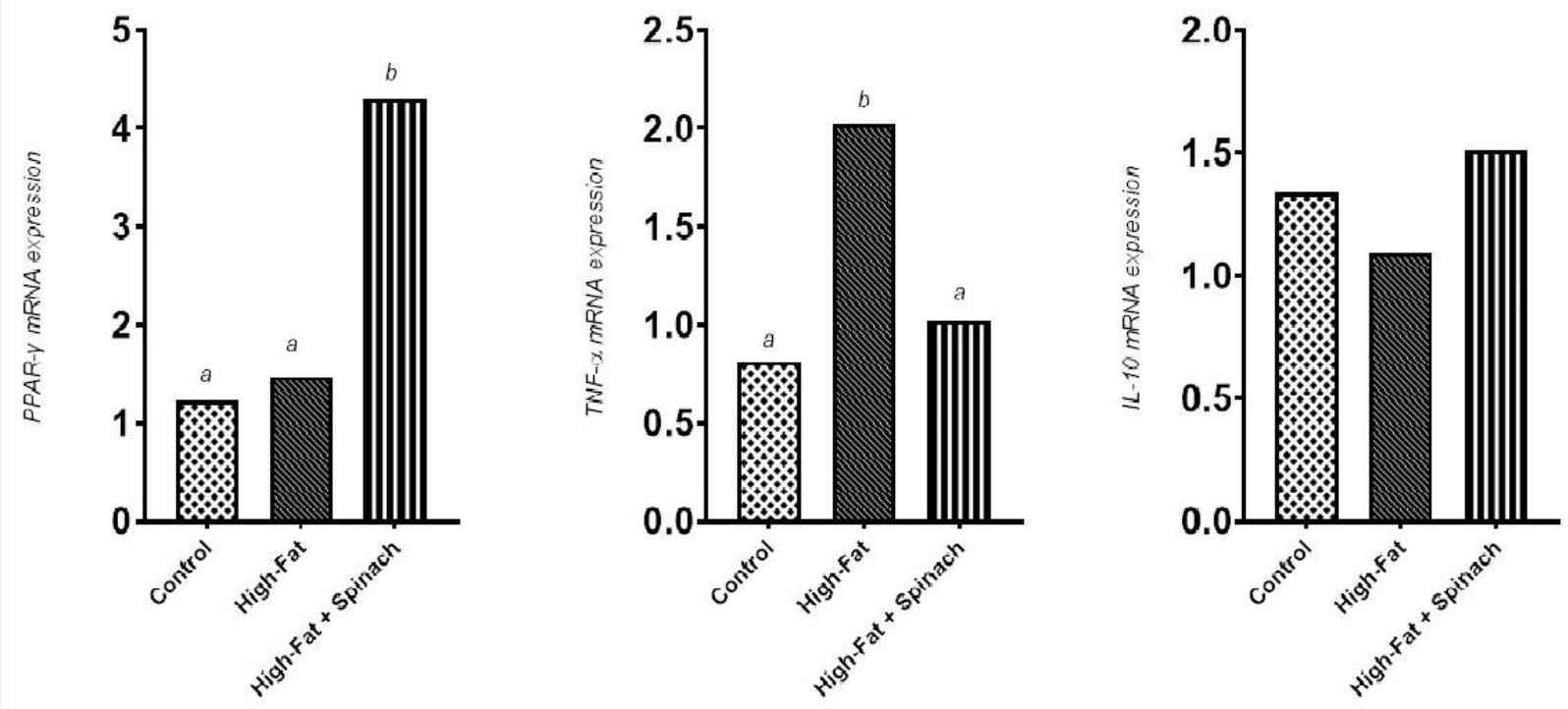

\subsection{Treatment phase}

Total weight gain and food intake were significantly higher in the rats on the high-fat diet compared to the rats on the normal chow diet $(P<0.001)$. However, receiving HES could not make any significant improvements in body weight and food intake in the treatment phase. Serum levels of hs-CRP and PTX-3 were significantly lower in TFS group compared to TF group at the end of the treatment phase $(P=0.02)$. The rats in TFS group had a higher serum levels of TAC compared to the TF group at the end of the study $(P=0.03)$. Four weeks of supplementation with spinach extract in rats of TCS and TFS groups significantly increased the activity of liver GPX compared to TC and TF groups $(P=0.01)$. The rats in the high-fat group had higher serum levels of MMP-9 compared to those on the normal chow diet $(P=0.02)$. No statistical differences were observed regarding other markers among other groups (Table 3). 
Supplementation with HES significantly increased liver gene expression of PPAR- $\gamma$ compared to the control group $(P<0.01)$. Hepatic gene expression of PPAR- $\gamma$ in TFS group was also higher than in the TCS group at the end of the treatment phase $(P<0.01)$. Liver gene expression of TNF$\alpha$ was significantly higher in the TF group compared to other groups at the end of the prevention phase $(P<0.01)$. No significant changes were seen regarding IL-10 among groups (shown in Fig. 2).

Table 3. Weight gain, total food intake, serum inflammation and oxidative stress biomarkers and antioxidant enzyme activity in liver at the end of the treatment phase.

\begin{tabular}{|c|c|c|c|c|c|}
\hline & $\begin{array}{l}\text { Control } \\
(n=6)\end{array}$ & $\begin{array}{l}\text { Control+ } \\
\text { Spinach } \\
(\mathrm{n}=6)\end{array}$ & $\begin{array}{l}\text { High-fat } \\
(n=6)\end{array}$ & $\begin{array}{l}\text { High-fat+ Spinach } \\
(n=6)\end{array}$ & $\begin{array}{l}P \text { value, } \\
\text { ANOVA }\end{array}$ \\
\hline Weight gain(g) & $-22 \pm 22^{a}$ & $-22.8 \pm 18.4^{\mathrm{a}}$ & $16.8 \pm 7.8^{\mathrm{b}}$ & $12.3 \pm 10.2^{\mathrm{b}}$ & $<0.001^{*}$ \\
\hline Food intake(g) & $77.7 \pm 5.1^{\mathrm{a}}$ & $82.1 \pm 6.4^{\mathrm{a}}$ & $111.5 \pm 16.8^{b}$ & $102.7 \pm 7.6^{b}$ & $<0.001^{*}$ \\
\hline $\operatorname{CCK}(n g / l)$ & $117.5 \pm 48.9$ & $116.4 \pm 29.8$ & $127.5 \pm 23.1$ & $133.8 \pm 17.5$ & 0.75 \\
\hline Hs_CRP(ng/ml) & $3.48 \pm 0.62^{\mathrm{a}}$ & $3.68 \pm 0.43^{\mathrm{a}}$ & $4.69 \pm 0.96^{b}$ & $3.68 \pm 0.64^{\mathrm{a}}$ & $0.02^{*}$ \\
\hline PTX-3(ng/ml) & $0.63 \pm 0.14^{\mathrm{a}}$ & $0.63 \pm 0.09^{\mathrm{a}}$ & $0.86 \pm 0.1^{b}$ & $0.67 \pm 0.17^{\mathrm{a}}$ & $0.02^{*}$ \\
\hline MMP-9(ng/ml) & $0.5 \pm 0.09^{\mathrm{a}}$ & $0.52 \pm 0.19^{\mathrm{a}}$ & $0.81 \pm 0.22^{\mathrm{b}}$ & $0.64 \pm 0.17^{\mathrm{ab}}$ & $0.02^{*}$ \\
\hline TAC $(\mu \mathrm{mol} / \mathrm{l})$ & $214(181.5-219.2)^{\mathrm{ab}}$ & $204(199-216.5)^{a}$ & $186(180.5-191.2)^{\mathrm{b}}$ & $209(205.5-212)^{\mathrm{a}}$ & $0.03^{* \dagger}$ \\
\hline $\operatorname{GPX}(\mathbf{U} / \mathbf{m l})$ & $233.8 \pm 33.5^{\mathrm{a}}$ & $365.9 \pm 115.7^{b}$ & $224.6 \pm 51.7^{\mathrm{a}}$ & $336.1 \pm 86.1^{\mathrm{b}}$ & $0.01^{*}$ \\
\hline $\operatorname{SOD}(\mathbf{U} / \mathrm{ml})$ & $56 \pm 25.5$ & $59.9 \pm 14.2$ & $44.4 \pm 14.6$ & $70.7 \pm 16.1$ & 0.12 \\
\hline Steatosis score & $0(0-0.25)^{\mathrm{a}}$ & $0^{\mathrm{a}}$ & $2(1-2)^{\mathrm{b}}$ & $1(0-1)^{\mathrm{a}}$ & $0.001^{* \dagger}$ \\
\hline NAS score & $1(0-2)^{\mathrm{a}}$ & $1(0-2)^{\mathrm{a}}$ & $4(3-5)^{b}$ & $2(0-4)^{\mathrm{ab}}$ & $0.007^{* \dagger}$ \\
\hline
\end{tabular}

Values are expressed as mean \pm SD for data with normal distribution and median (IQR) for those with non-normal distribution. $\mathrm{CCK}=$ Cholecystokinin, Hs_CRP= High-sensitivity C-reactive Protein, PTX-3= Pentraxin-3, MMP-9= Matrix metalloproteinase$9, \mathrm{TAC}=$ Total antioxidant capacity, $\mathrm{GPX}=$ Glutathione peroxidase, $\mathrm{SOD}=$ Superoxide dismutase Different letters show significantly different at $P<0.05$.

† Kruskal-Wallis test

Fig. 2. Liver gene expression of PPAR- $\gamma$, TNF- $\alpha$, and IL-10 at the end of the treatment phase. 
Different letters show significantly different at $\mathrm{P}<0.05$.
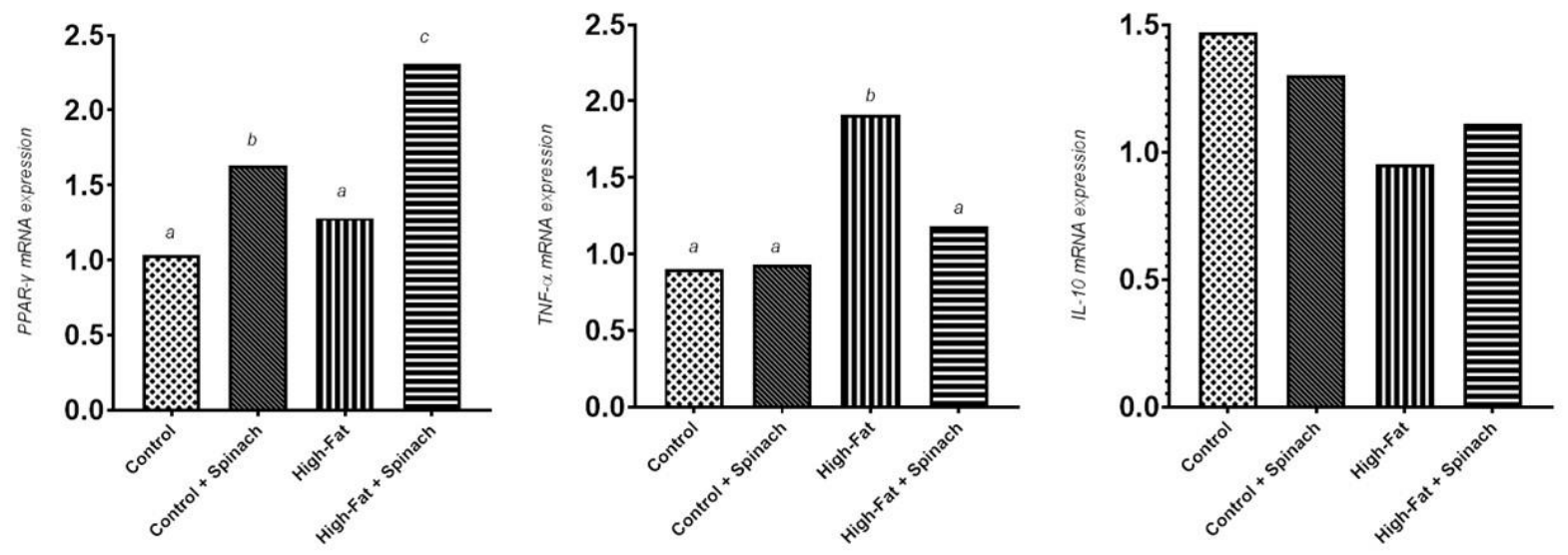

\section{Discussion}

In this experimental study on rat NAFLD models, we found that compared to the HF diet, HF diet+HES reduced food intake and weight gain in the prevention phase; however, it did not have any impact on these variables in the treatment phase. Furthermore, HES decreased TNF- $\alpha$ gene expression, hs-CRP and PTX-3; and increased PPAR- $\gamma$ gene expression and liver SOD activity in the prevention phase. Additionally, HES reduced TNF- $\alpha$ gene expression, hs-CRP, and PTX-3; and increased PPAR- $\gamma$ gene expression, TAC, and liver GPX activity in the treatment phase.

The intake of HF diet and the subsequent weight gain were higher in rat NAFLD models in both phases of the study, presumably attributable to the greater palatability, softer texture, and higher energy content of this regimen. Adding HES to the diet of rats decreased food intake and led to weight loss in the prevention phase; nonetheless, we were not able to make the same observation in the treatment phase. Previous experimental studies have also shown appetite- and weight- 
reducing properties of HES supplementation at a dose of $200 \mathrm{mg} / \mathrm{kg}$ and $400 \mathrm{mg} / \mathrm{kg}$ for 14 days in one study (31), as well as administration of spinach-derived thylakoids for 2 weeks in high-fat fed mice in another (34). Moreover, in a study of overweight women receiving $5 \mathrm{~g} / \mathrm{d}$ of thylakoid over a period of 12 weeks, body weight decreased (35); on the contrary, in a similar study consisting a dosage of $5.6 \mathrm{~g} / \mathrm{d}$ administered during eight weeks of intervention, no weight loss was observed (36). Some of the mechanisms that have been suggested for this appetite-reducing feature of spinach and specifically its active ingredient, thylakoid, include the following: 1) inhibition of lipase/colipase and substrate complex formation $(37), 2$ ) reducing the rate of gastric emptying and, in turn, increasing CCK and GLP-1 secretion (17, 18, 35, 38), 3) decreasing ghrelin secretion (39), and 4) stimulation of enterostatin secretion (37). In the two phases of our study, there was no increase in serum levels of CCK; in contrast to the previous human- and animal-based evidence $(17,31,37)$. Previous studies have measured CCK levels shortly after receiving spinach, while we measured it after 12 hours of fasting; therefore, it is deductible that the CCK-promoting effect of spinach is only expected to last for a short period of time and immediately after the meals. The lack of effect of spinach on appetite and weight loss in the treatment phase can be attributed to the shorter duration of intervention and the impairment of appetite-regulatory mechanisms due to the induction of NAFLD using HF diet (40).

Administration of HES improved SOD activity in the prevention phase and promoted GPx enzyme activity in the treatment phase in the liver of the rats. The HES intake also increased serum TAC in the treatment phase. Existing evidence shows that spinach has the highest antioxidant capacity among vegetables $(41,42)$. This characteristic has been previously observed in numerous animal and human studies using various types of spinach. In one study, consumption of spinach powder (\%5 of diet) for 6 weeks increased SOD activity in liver of the rats (43). Panda et al. showed that 
200 and $400 \mathrm{mg} / \mathrm{kg}$ HES for 45 days in rats, as part of a high-fructose diet, enhances the activity of SOD and GPx in heart (44). In a clinical trial, Bohlooli et al. evaluated the effects of spinach supplementation on antioxidant status and muscle injury in marathon runners. After 14 days of spinach supplementation $(1 \mathrm{mg} / \mathrm{kg}$ ), serum TAC levels were significantly increased compared to the control group (45). Previous studies have postulated the following mechanisms as possible pathways by which spinach may exert its antioxidant properties: scavenging the radicals of 2,2'azino-bis(3-ethylbenzothiazoline-6-sulfonic acid) (ABTS), superoxide anion $\left(\mathrm{O}_{2}\right), \mathrm{Fe}^{2+}$, peroxyl, and proxy nitrate in in-vitro setting $(46,47)$. Evidence suggests that spinach consumption increases serum lutein levels $(48,49)$. Lutein can protect the body against radical oxygen species (ROSs) by scavenging the hydroxyl and superoxide radicals, and also inducing antioxidant enzymes (i.e. catalase, SOD, GPx, and glutathione reductase) $(50,51)$. Conclusively, spinach can have protective impacts against oxidative stress by enhancing serum levels of lutein and promoting the activity of antioxidant systems of the body; our findings are in line with these observations.

Regarding the possible effect of spinach on inflammatory parameters, we measured the effect of spinach supplementation on some inflammatory cytokines; both in terms of gene expression (IL10 and TNF- $\alpha$ ) and serum levels (hs-CRP and PTX-3). In our study, administration of HES decreased hs-CRP and PTX-3 serum levels and demoted TNF- $\alpha$ gene expression, in both prevention and treatment phases; to our knowledge this observation is unprecedented. Previous to this study, only one clinical trial examined the effect of supplementation with spinach powder (10.4 g / day) on serum CRP levels in which the intake of spinach for 8 weeks had no effect on serum CRP levels in healthy subjects (52). It is worthy of note that in the present examination, hsCRP was measured instead of conventional CRP which is more sensitive and is able to detect CRP in smaller quantities(53).This should also be taken into account that we used spinach extract 
instead of the foodstuff and it was administered to the rats, not human subjects. This fact may have caused some overestimation as to the efficacy of spinach, thus larger doses of spinach may be needed to exert similar effects on human subjects.

Addition of glycolipids extracted from spinach to the in-vitro culture medium of umbilical vein endothelial cells reduced the expression of IL-6 and other lipopolysaccharide (LPS) -induced inflammatory factors by inhibiting phosphorylation and inactivation of the NF- $\mathrm{KB}$ pathway (54). Lutein, found abundantly in spinach, decreased plasma levels of prostaglandin E2, TNF- $\alpha$, interleukin-1- $\beta$, the activity of nitric oxide (iNOS), and cyclooxygenase 2 (COX-2) in the liver; it also inhibited NF-אB signaling pathway that can play an important role in reducing inflammation (55). Likewise, consumption of spinach antioxidants has been associated with improved LPSinduced inflammation in animal studies $(56,57)$. Inflammatory cytokines, especially TNF- $\alpha$, are the main stimuli of PTX-3 production, an acute phase protein in the body $(58,59)$. To sum up, spinach and its compounds can inhibit the expression of CRP and PTX-3 by blocking the NF- $\mathrm{KB}$ pathway and reducing the production of IL-6, IL-1, and TNF- $\alpha$ (60). Previous studies have not investigated the effect of spinach on IL-10 as an anti-inflammatory cytokine. Few animal studies have shown that lutein supplementation can increase IL-10 levels $(61,62)$. A longer intervention and a higher dose of HES may be needed to increase IL-10 in rat NAFLD models.

The administration of HES in our study did not change serum levels of MMP-9, either in the prevention nor in the treatment phase. Studies have shown that abnormal accumulation of collagen in the liver and progression of NAFLD to NASH and cirrhosis increase MMP-9 serum levels (21, 22, 63). We also observed higher serum levels of MMP-9 in the HF diet group compared to the control group; these results are also in line with previous findings. We were not able to find any investigations that had examined the effect of spinach intake on MMP-9 levels; however, a couple 
of studies have shown favorable effects of quercetin, one of the spinach flavonoids, on reducing MMP-9 levels $(64,65)$. In these studies the use of pure quercetin which contains higher amount of quercetin than HES and the small sample size of our study might be the reason as to why we were not able to detect a any such impact on MMP-9 levels.

Spinach extract resulted in increased expression of PPAR- $\gamma$ gene in rat liver in both the prevention and treatment phases. This increase was greater in the prevention phase than in the treatment phase, which appears to be due to the longer period of spinach intake in the prevention phase ( 7 weeks), compared to the treatment phase (4 weeks). Elvira-Torales LI et al. administered spinach powder to the rats (5\% diet) for two weeks; similar to our findings, the expression of PPAR- $\gamma$ gene in the liver was enhanced compared with the control group (28). Also, in a study by Stenkula et al. on 30 rats, two weeks of supplementation with spinach thylakoids (33\% diet) resulted in increased PPAR- $\gamma$ gene expression in adipose tissue compared to the control group (34).

Activation of PPAR- $\gamma$ results in improved insulin sensitivity in peripheral tissues, such as adipose tissue and skeletal muscle; thereby, reduces the transfer of fatty acids to the liver (66-68). Activation of PPAR- $\gamma$ reduces insulin resistance by increasing adiponectin levels (69); adiponectin, in turn, reduces lipid accumulation in the liver and contributes further to the antiinflammatory effects of PPAR- $\gamma$ by enhancing PPAR- $\alpha$ activity and fatty acid oxidation (70-72). PPAR- $\gamma$ inhibits TGF $\beta-1$ signaling pathway and induces apoptosis that prevents liver stellate cells activation and proliferation and their conversion to fibrotic form (73-77). Previous studies have reported the positive effects of the use of PPAR- $\gamma$ agonists, e.g. thiazolidinediones, in improving blood glucose, lipids profile and liver enzymes, and reducing steatosis and inflammation in patients with fatty liver $(78,79)$. However, widespread reports of side-effects, such as overweight, heart failure, bone fractures, and bladder cancer have limited the widespread use of thiazolidinediones 
$(80,81)$. Weaker PPAR- $\gamma$ agonists are naturally present in some plants that partially activate PPAR- $\gamma$ compared to TZDs. These compounds, known as selective PPAR- $\gamma$ modulators (SPPARMs) can improve glucose homeostasis without causing side effects (82). These natural compounds include catechin, quercetin, and kaempferol (83); all these compounds are present in spinach (84), which can justify the beneficial effects of spinach in improving fatty liver disease.

In this study, a diet consisting of sugar, egg yolk, and butter was used to induce NAFLD in rats, which is a similar dietary pattern most associated with NAFLD pathogenesis in humans. We also used hydro-alcoholic extract that contains both water-soluble and fat-soluble spinach compounds, in contrast to the aqueous or alcoholic extracts. In this study the effects of HES in two phases of prevention and treatment were investigated. In addition, adding the Chow + HES group and comparing it with the Chow group in the treatment phase, allowed us to examine the simultaneous effects of diet modification and spinach intake. Other strengths of the present study are measurement of the effect of HES on some indices, such as hs-CRP, MMP-9 and PTX-3 for the first time. However, our study also had some limitations: 1) further biochemical analyses and measurements of effective constituents in HES could help us to better interpret our finding; this was rendered impossible due to the budget constraints, 2) we were able to investigate the effects of only a single dose (instead of examining multiple dosages), and 3) lack of dose-related relationships.

Regarding the favorable effects of HES on NAFLD indices in the present study, we propose that further clinical investigations be conducted on human subjects with NAFLD.

\section{Conclusions}


In general, the results of this study showed that the administration of HES when combined with HF diet was associated with decreased food intake, weight loss, and increased SOD enzyme activity in the liver in rats. Moreover, hs-CRP, PTX-3, PPAR- $\gamma$, and TNF- $\alpha$ gene expression in the liver were improved by spinach administration, both in the prevention and treatment phases. In addition, administration of spinach in the treatment phase was associated with increased serum TAC and increased hepatic GPX enzyme activity. Spinach extract had no effect on CCK, MMP9, and IL-10 gene expressions.

\section{Declaration}

\section{Ethics approval}

All animal procedures were carried out in accordance with the Iran University of Medicals Sciences ethics committee (IR.IUMS.REC) and the study protocol was approved by IR.IUMS.REC with ethics code of IR.IUMS.REC 1396.9511468001. The study was carried out in compliance with the ARRIVE guidelines. 


\section{Data availability}

All data generated or analyzed during this study are included in this published article [and its supplementary information files].

\section{Conflict of interest}

The authors have no conflict of interest to declare.

\section{Funding}

This study was supported by Iran University of Medical Sciences (IUMS), Tehran, Iran [grant number 32643].

\section{Acknowledgments and author contributions}

We are grateful to our co-workers. A.A, A.H and F.SH provided study concepts and designed the study. A.A, AS, FM, and MS conducted the research. A.A took part in data analysis, interpretation and statistical analysis. A.A, HE and F.SH contributed to manuscript preparation, editing and review. All authors read and approved the final manuscript.

\section{References}

1. Mavrogiannaki AN, Migdalis IN. Nonalcoholic Fatty liver disease, diabetes mellitus and cardiovascular disease: newer data. Int J Endocrinol. 2013;450639(10):3.

2. McCullough AJ. The clinical features, diagnosis and natural history of nonalcoholic fatty liver disease. Clinics in liver disease. 2004;8(3):521-33, viii.

3. Serfaty L, Lemoine M. Definition and natural history of metabolic steatosis: clinical aspects of NAFLD, NASH and cirrhosis. Diabetes \& metabolism. 2008;34(6 Pt 2):634-7.

4. Matteoni CA, Younossi ZM, Gramlich T, Boparai N, Liu YC, McCullough AJ. Nonalcoholic fatty liver disease: a spectrum of clinical and pathological severity. Gastroenterology. 1999;116(6):1413-9.

5. Musso G, Gambino R, De Michieli F, Cassader M, Rizzetto M, Durazzo M, et al. Dietary habits and their relations to insulin resistance and postprandial lipemia in nonalcoholic steatohepatitis. Hepatology (Baltimore, Md). 2003;37(4):909-16. 
6. McCullough AJ. Pathophysiology of nonalcoholic steatohepatitis. Journal of clinical gastroenterology. 2006;40 Suppl 1:S17-29.

7. Wong VW, Chan RS, Wong GL, Cheung BH, Chu WC, Yeung DK, et al. Community-based lifestyle modification programme for non-alcoholic fatty liver disease: a randomized controlled trial. Journal of hepatology. 2013;59(3):536-42.

8. Vilar-Gomez E, Martinez-Perez Y, Calzadilla-Bertot L, Torres-Gonzalez A, Gra-Oramas B, Gonzalez-Fabian L, et al. Weight Loss Through Lifestyle Modification Significantly Reduces Features of Nonalcoholic Steatohepatitis. Gastroenterology. 2015;149(2):367-78.e5; quiz e14-5.

9. Laursen TL, Hagemann CA, Wei C, Kazankov K, Thomsen KL, Knop FK, et al. Bariatric surgery in patients with non-alcoholic fatty liver disease - from pathophysiology to clinical effects. World J Hepatol. 2019;11(2):138-49.

10. Townsend SA, Newsome PN. Review article: new treatments in non-alcoholic fatty liver disease. 2017;46(5):494-507.

11. Lee J, Lee S, Lee H, Park K, Choe E. Spinach (Spinacia oleracea) powder as a natural food-grade antioxidant in deep-fat-fried products. J Agric Food Chem. 2002;50(20):5664-9.

12. Bergman M, Varshavsky L, Gottlieb HE, Grossman S. The antioxidant activity of aqueous spinach extract: chemical identification of active fractions. Phytochemistry. 2001;58(1):143-52.

13. Roberts JL, Moreau R. Functional properties of spinach (Spinacia oleracea L.) phytochemicals and bioactives. Food Funct. 2016;7(8):3337-53.

14. Emek SC, Akerlund HE, Erlanson-Albertsson C, Albertsson PA. Pancreatic lipase-colipase binds strongly to the thylakoid membrane surface. J Sci Food Agric. 2013;93(9):2254-8.

15. Albertsson P-Å, Köhnke R, Emek Sinan C, Mei J, Rehfeld Jens F, Åkerlund H-E, et al. Chloroplast membranes retard fat digestion and induce satiety: effect of biological membranes on pancreatic lipase/co-lipase. Biochemical Journal. 2007;401(3):727.

16. Kohnke R, Lindqvist A, Goransson N, Emek SC, Albertsson PA, Rehfeld JF, et al. Thylakoids suppress appetite by increasing cholecystokinin resulting in lower food intake and body weight in highfat fed mice. Phytother Res. 2009;23(12):1778-83.

17. Kohnke R, Lindbo A, Larsson T, Lindqvist A, Rayner M, Emek SC, et al. Thylakoids promote release of the satiety hormone cholecystokinin while reducing insulin in healthy humans. Scandinavian journal of gastroenterology. 2009;44(6):712-9.

18. Stenblom EL, Montelius C, Ostbring K, Hakansson M, Nilsson S, Rehfeld JF, et al.

Supplementation by thylakoids to a high carbohydrate meal decreases feelings of hunger, elevates CCK levels and prevents postprandial hypoglycaemia in overweight women. Appetite. 2013;68:118-23.

19. Amirinejad A, Heshmati J, Shidfar F. Effects of thylakoid intake on appetite and weight loss: a systematic review. Journal of Diabetes \& Metabolic Disorders. 2019.

20. Stenkula KG, Stenblom E-L, Montelius C, Egecioglu E, Erlanson-Albertsson C. Thylakoids reduce body fat and fat cell size by binding to dietary fat making it less available for absorption in high-fat fed mice. Nutrition \& metabolism. 2017;14:4-.

21. Ljumovic D, Diamantis I, Alegakis AK, Kouroumalis EA. Differential expression of matrix metalloproteinases in viral and non-viral chronic liver diseases. Clinica chimica acta; international journal of clinical chemistry. 2004;349(1-2):203-11.

22. D'Amico F, Consolo M, Amoroso A, Skarmoutsou E, Mauceri B, Stivala F, et al. Liver immunolocalization and plasma levels of MMP-9 in non-alcoholic steatohepatitis (NASH) and hepatitis C infection. Acta histochemica. 2010;112(5):474-81.

23. Boga S, Koksal AR, Alkim H, Yilmaz Ozguven MB, Bayram M, Ergun M, et al. Plasma Pentraxin 3 Differentiates Nonalcoholic Steatohepatitis (NASH) from Non-NASH. Metab Syndr Relat Disord. 2015;13(9):393-9. 
24. Hanley AJ, Williams K, Festa A, Wagenknecht LE, D'Agostino RB, Jr., Haffner SM. Liver markers and development of the metabolic syndrome: the insulin resistance atherosclerosis study. Diabetes. 2005;54(11):3140-7.

25. Maciejewska D, Lukomska A, Dec K, Skonieczna-Zydecka K, Gutowska I, Skorka-Majewicz M, et al. Diet-Induced Rat Model of Gradual Development of Non-Alcoholic Fatty Liver Disease (NAFLD) with Lipopolysaccharides (LPS) Secretion. Diagnostics (Basel, Switzerland). 2019;9(4).

26. Louis H, Le Moine O, Peny MO, Gulbis B, Nisol F, Goldman M, et al. Hepatoprotective role of interleukin 10 in galactosamine/lipopolysaccharide mouse liver injury. Gastroenterology. 1997;112(3):935-42.

27. Douglas DB, Beiting DP, Loftus JP, Appleton JA, Bliss SK. Combinatorial effects of interleukin 10 and interleukin 4 determine the progression of hepatic inflammation following murine enteric parasitic infection. Hepatology (Baltimore, Md). 2010;51(6):2162-71.

28. Elvira-Torales LI, Periago MJ, Gonzalez-Barrio R, Hidalgo N, Navarro-Gonzalez I, Gomez-Gallego $C$, et al. Spinach consumption ameliorates the gut microbiota and dislipaemia in rats with diet-induced non-alcoholic fatty liver disease (NAFLD). Food Funct. 2019;10(4):2148-60.

29. Amirinejad A, Hekmatdoost A, Ebrahimi A, Ranjbaran F, Shidfar F. The effects of hydroalcoholic extract of spinach on prevention and treatment of some metabolic and histologic features in a rat model of nonalcoholic fatty liver disease. 2020;100(4):1787-96.

30. Emamat $H$, Noori M, Foroughi F, Rismanchi M, Eini-Zinab H, Hekmatdoost A. An Accessible and Pragmatic Experimental Model of Nonalcoholic Fatty Liver Disease. Middle East J Dig Dis. 2016;8(2):10915.

31. Panda V, Shinde P. Appetite suppressing effect of Spinacia oleracea in rats: Involvement of the short term satiety signal cholecystokinin. Appetite. 2017;113:224-30.

32. Panda V, Mistry K, Sudhamani S, Nandave M, Ojha SK. Amelioration of Abnormalities Associated with the Metabolic Syndrome by Spinacia oleracea (Spinach) Consumption and Aerobic Exercise in Rats. Oxidative Medicine and Cellular Longevity. 2017;2017:15.

33. Kozera B, Rapacz M. Reference genes in real-time PCR. J Appl Genet. 2013;54(4):391-406.

34. Stenkula KG, Stenblom EL, Montelius C, Egecioglu E, Erlanson-Albertsson C. Thylakoids reduce body fat and fat cell size by binding to dietary fat making it less available for absorption in high-fat fed mice. Nutr Metab (Lond). 2017;14:4.

35. Montelius C, Erlandsson D, Vitija E, Stenblom EL, Egecioglu E, Erlanson-Albertsson C. Body weight loss, reduced urge for palatable food and increased release of GLP-1 through daily supplementation with green-plant membranes for three months in overweight women. Appetite. 2014;81:295-304.

36. Stenblom E-L, Montelius C, Erlandsson D, Skarping L, Fransson M, Egecioglu E, et al. Decreased urge for palatable food after a two-month dietary intervention with green-plant membranes in overweight women. Journal of Obesity \& Weight Loss Therapy. 2014;4.

37. Albertsson PA, Kohnke R, Emek SC, Mei J, Rehfeld JF, Akerlund HE, et al. Chloroplast membranes retard fat digestion and induce satiety: effect of biological membranes on pancreatic lipase/co-lipase. The Biochemical journal. 2007;401(3):727-33.

38. Stenblom E-L, Weström B, Linninge C, Bonn P, Farrell M, Rehfeld JF, et al. Dietary green-plant thylakoids decrease gastric emptying and gut transit, promote changes in the gut microbial flora, but does not cause steatorrhea. Nutrition \& Metabolism. 2016;13(1):67.

39. Degen L, Drewe J, Piccoli F, Grani K, Oesch S, Bunea R, et al. Effect of CCK-1 receptor blockade on ghrelin and PYY secretion in men. American journal of physiology Regulatory, integrative and comparative physiology. 2007;292(4):R1391-9. 
40. Speechly DP, Buffenstein R. Appetite dysfunction in obese males: evidence for role of hyperinsulinaemia in passive overconsumption with a high fat diet. European journal of clinical nutrition. 2000;54(3):225-33.

41. Abid MA, Ashfaq M, Sharif MJH, Rauf K, Mahmood W, Khan I, et al. Total antioxidant capacity of commonly used fruits, vegetables, herbs and spices of Pakistan. Pakistan journal of pharmaceutical sciences. 2017;30(6):2147-50.

42. Pellegrini N, Serafini M, Colombi B, Del Rio D, Salvatore S, Bianchi M, et al. Total antioxidant capacity of plant foods, beverages and oils consumed in Italy assessed by three different in vitro assays. The Journal of nutrition. 2003;133(9):2812-9.

43. Ko SH, Park JH, Kim SY, Lee SW, Chun SS, Park E. Antioxidant Effects of Spinach (Spinacia oleracea L.) Supplementation in Hyperlipidemic Rats. Preventive nutrition and food science. 2014;19(1):19-26.

44. Panda V, Mistry K, Sudhamani S, Nandave M, Ojha SK. Amelioration of Abnormalities Associated with the Metabolic Syndrome by Spinacia oleracea (Spinach) Consumption and Aerobic Exercise in Rats. Oxidative medicine and cellular longevity. 2017;2017:2359389.

45. Bohlooli S, Barmaki S, Khoshkhahesh F, Nakhostin-Roohi B. The effect of spinach supplementation on exercise-induced oxidative stress. The Journal of sports medicine and physical fitness. 2015;55(6):609-14.

46. Chu YF, Sun J, Wu X, Liu RH. Antioxidant and antiproliferative activities of common vegetables. J Agric Food Chem. 2002;50(23):6910-6.

47. Zhou K, Yu L. Total phenolic contents and antioxidant properties of commonly consumed vegetables grown in Colorado. LWT - Food Science and Technology. 2006;39(10):1155-62.

48. Pool-Zobel BL, Bub A, Muller H, Wollowski I, Rechkemmer G. Consumption of vegetables reduces genetic damage in humans: first results of a human intervention trial with carotenoid-rich foods. Carcinogenesis. 1997;18(9):1847-50.

49. Castenmiller JJM, Lauridsen ST, Dragsted LO, Hof KHvh, Linssen JPH, West CE. $\beta$-Carotene Does Not Change Markers of Enzymatic and Nonenzymatic Antioxidant Activity in Human Blood. The Journal of nutrition. 1999;129(12):2162-9.

50. Sindhu ER, Preethi KC, Kuttan R. Antioxidant activity of carotenoid lutein in vitro and in vivo. Indian journal of experimental biology. 2010;48(8):843-8.

51. Pool-Zobel BL, Bub A, Liegibel UM, Treptow-van Lishaut S, Rechkemmer G. Mechanisms by which vegetable consumption reduces genetic damage in humans. Cancer Epidemiology Biomarkers \&amp;amp; Prevention. 1998;7(10):891.

52. Graydon R, Hogg RE, Chakravarthy U, Young IS, Woodside JV. The effect of lutein- and zeaxanthin-rich foods $\mathrm{v}$. supplements on macular pigment level and serological markers of endothelial activation, inflammation and oxidation: pilot studies in healthy volunteers. The British journal of nutrition. 2012;108(2):334-42.

53. Yucel D. C-Reactive protein vs. high-sensitivity C-reactive protein: What is the difference? Turk J Biochem. 2014;39:43-4.

54. Ishii M, Nakahara T, Araho D, Murakami J, Nishimura M. Glycolipids from spinach suppress LPSinduced vascular inflammation through eNOS and NK-kappaB signaling. Biomedicine \& pharmacotherapy = Biomedecine \& pharmacotherapie. 2017;91:111-20.

55. Kim JH, Na HJ, Kim CK, Kim JY, Ha KS, Lee H, et al. The non-provitamin A carotenoid, lutein, inhibits NF-kappaB-dependent gene expression through redox-based regulation of the phosphatidylinositol 3-kinase/PTEN/Akt and NF-kappaB-inducing kinase pathways: role of $\mathrm{H}(2) \mathrm{O}(2)$ in NF-kappaB activation. Free radical biology \& medicine. 2008;45(6):885-96. 
56. Lomnitski L, Carbonatto M, Ben-Shaul V, Peano S, Conz A, Corradin L, et al. The prophylactic effects of natural water-soluble antioxidant from spinach and apocynin in a rabbit model of lipopolysaccharide-induced endotoxemia. Toxicologic pathology. 2000;28(4):588-600.

57. Lomnitski L, Foley JE, Grossman S, Shaul VB, Maronpot RR, Moomaw CR, et al. Effects of apocynin and natural antioxidant from spinach on inducible nitric oxide synthase and cyclooxygenase-2 induction in lipopolysaccharide-induced hepatic injury in rat. Pharmacology \& toxicology. 2000;87(1):1825.

58. Bottazzi B, Doni A, Garlanda C, Mantovani A. An integrated view of humoral innate immunity: pentraxins as a paradigm. Annual review of immunology. 2010;28:157-83.

59. Bottazzi B, Garlanda C, Cotena A, Moalli F, Jaillon S, Deban L, et al. The long pentraxin PTX3 as a prototypic humoral pattern recognition receptor: interplay with cellular innate immunity. Immunological reviews. 2009;227(1):9-18.

60. Agrawal A, Cha-Molstad H, Samols D, Kushner I. Overexpressed nuclear factor-kappaB can participate in endogenous C-reactive protein induction, and enhances the effects of C/EBPbeta and signal transducer and activator of transcription-3. Immunology. 2003;108(4):539-47.

61. Shanmugasundaram R, Selvaraj RK. Lutein supplementation alters inflammatory cytokine production and antioxidant status in F-line turkeys. Poultry science. 2011;90(5):971-6.

62. Kim JE, Leite JO, deOgburn R, Smyth JA, Clark RM, Fernandez ML. A Lutein-Enriched Diet Prevents Cholesterol Accumulation and Decreases Oxidized LDL and Inflammatory Cytokines in the Aorta of Guinea Pigs. The Journal of nutrition. 2011;141(8):1458-63.

63. Lichtinghagen $\mathrm{R}$, Breitenstein $\mathrm{K}$, Arndt $\mathrm{B}$, Kuhbacher T, Boker KH. Comparison of matrix metalloproteinase expression in normal and cirrhotic human liver. Virchows Archiv : an international journal of pathology. 1998;432(2):153-8.

64. Chen B, He T, Xing Y, Cao T. Effects of quercetin on the expression of MCP-1, MMP-9 and VEGF in rats with diabetic retinopathy. Experimental and therapeutic medicine. 2017;14(6):6022-6.

65. Cheng SC, Wu YH, Huang WC, Pang JS, Huang TH, Cheng CY. Anti-inflammatory property of quercetin through downregulation of ICAM-1 and MMP-9 in TNF-alpha-activated retinal pigment epithelial cells. Cytokine. 2019;116:48-60.

66. Lalloyer F, Staels B. Fibrates, glitazones, and peroxisome proliferator-activated receptors. Arteriosclerosis, thrombosis, and vascular biology. 2010;30(5):894-9.

67. Fievet C, Staels B. Efficacy of peroxisome proliferator-activated receptor agonists in diabetes and coronary artery disease. Current atherosclerosis reports. 2009;11(4):281-8.

68. Frayn KN. Adipose tissue as a buffer for daily lipid flux. Diabetologia. 2002;45(9):1201-10.

69. Maeda N, Takahashi M, Funahashi T, Kihara S, Nishizawa H, Kishida K, et al. PPARgamma ligands increase expression and plasma concentrations of adiponectin, an adipose-derived protein. Diabetes. 2001;50(9):2094-9.

70. Yamauchi T, Kamon J, Waki H, Terauchi Y, Kubota N, Hara K, et al. The fat-derived hormone adiponectin reverses insulin resistance associated with both lipoatrophy and obesity. Nature medicine. 2001;7(8):941-6.

71. Yamauchi T, Kamon J, Ito Y, Tsuchida A, Yokomizo T, Kita S, et al. Cloning of adiponectin receptors that mediate antidiabetic metabolic effects. Nature. 2003;423(6941):762-9.

72. Ouchi N, Kihara S, Arita Y, Okamoto Y, Maeda K, Kuriyama H, et al. Adiponectin, an adipocytederived plasma protein, inhibits endothelial NF-kappaB signaling through a cAMP-dependent pathway. Circulation. 2000;102(11):1296-301.

73. Galli A, Crabb DW, Ceni E, Salzano R, Mello T, Svegliati-Baroni G, et al. Antidiabetic thiazolidinediones inhibit collagen synthesis and hepatic stellate cell activation in vivo and in vitro. Gastroenterology. 2002;122(7):1924-40. 
74. Miyahara T, Schrum L, Rippe R, Xiong S, Yee HF, Jr., Motomura K, et al. Peroxisome proliferatoractivated receptors and hepatic stellate cell activation. The Journal of biological chemistry. 2000;275(46):35715-22.

75. Marra F, Efsen E, Romanelli RG, Caligiuri A, Pastacaldi S, Batignani G, et al. Ligands of peroxisome proliferator-activated receptor gamma modulate profibrogenic and proinflammatory actions in hepatic stellate cells. Gastroenterology. 2000;119(2):466-78.

76. Zhao C, Chen W, Yang L, Chen L, Stimpson SA, Diehl AM. PPARgamma agonists prevent TGFbeta1/Smad3-signaling in human hepatic stellate cells. Biochemical and biophysical research communications. 2006;350(2):385-91.

77. Wang X, Huang G, Mei S, Qian J, Ji J, Zhang J. Over-expression of C/EBP-alpha induces apoptosis in cultured rat hepatic stellate cells depending on $\mathrm{p} 53$ and peroxisome proliferator-activated receptorgamma. Biochemical and biophysical research communications. 2009;380(2):286-91.

78. Belfort R, Harrison SA, Brown K, Darland C, Finch J, Hardies J, et al. A placebo-controlled trial of pioglitazone in subjects with nonalcoholic steatohepatitis. The New England journal of medicine. 2006;355(22):2297-307.

79. Sanyal AJ, Chalasani N, Kowdley KV, McCullough A, Diehl AM, Bass NM, et al. Pioglitazone, vitamin $\mathrm{E}$, or placebo for nonalcoholic steatohepatitis. The New England journal of medicine. 2010;362(18):1675-85.

80. Cariou B, Charbonnel B, Staels B. Thiazolidinediones and PPARgamma agonists: time for a reassessment. Trends in endocrinology and metabolism: TEM. 2012;23(5):205-15.

81. Hirose H, Kawai T, Yamamoto Y, Taniyama M, Tomita M, Matsubara K, et al. Effects of pioglitazone on metabolic parameters, body fat distribution, and serum adiponectin levels in Japanese male patients with type 2 diabetes. Metabolism: clinical and experimental. 2002;51(3):314-7.

82. Higgins LS, Depaoli AM. Selective peroxisome proliferator-activated receptor gamma (PPARgamma) modulation as a strategy for safer therapeutic PPARgamma activation. The American journal of clinical nutrition. 2010;91(1):267s-72s.

83. Wang L, Waltenberger B, Pferschy-Wenzig EM, Blunder M, Liu X, Malainer C, et al. Natural product agonists of peroxisome proliferator-activated receptor gamma (PPARgamma): a review. Biochemical pharmacology. 2014;92(1):73-89.

84. Dehkharghanian M, Adenier H, Vijayalakshmi MA. Study of flavonoids in aqueous spinach extract using positive electrospray ionisation tandem quadrupole mass spectrometry. Food Chemistry. 2010;121(3):863-70. 
Figures
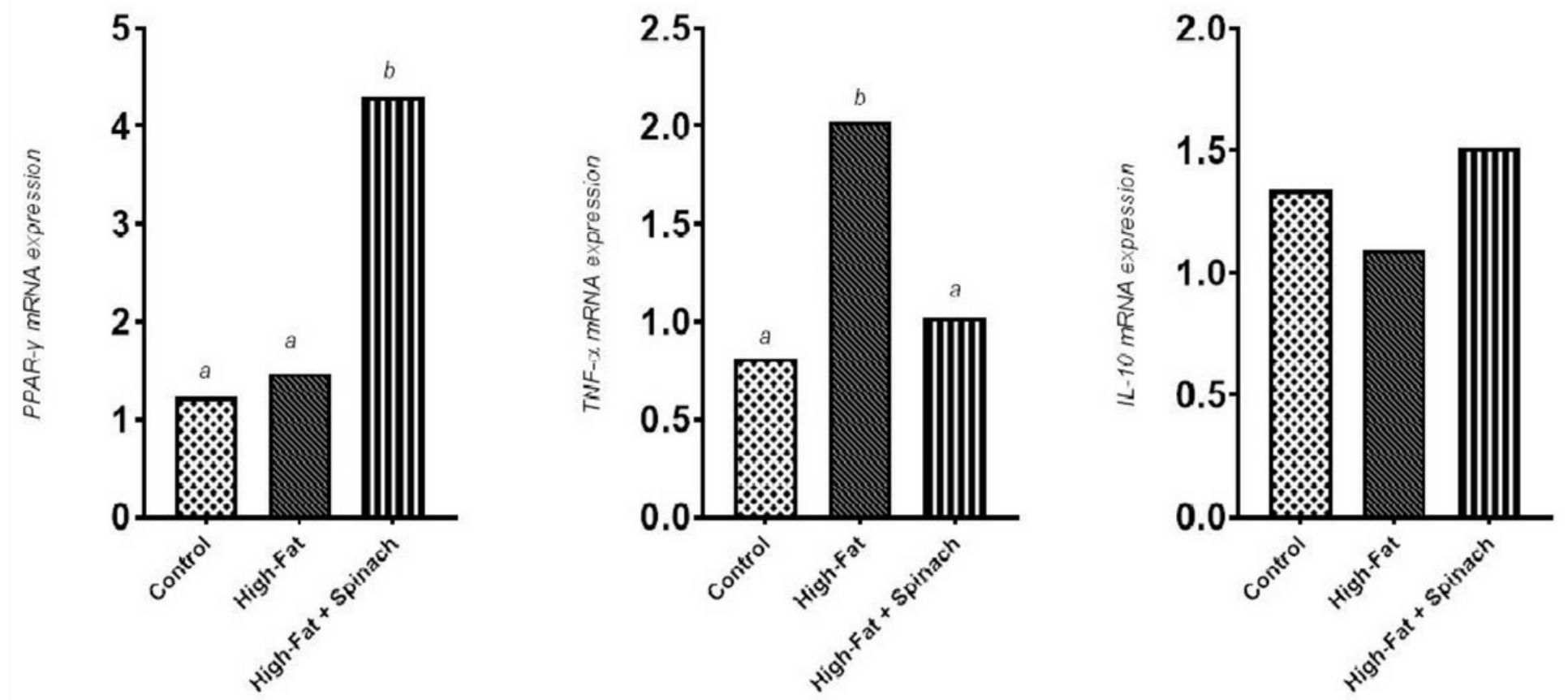

Figure 1

Liver gene expression of PPAR- $y$, TNF- $a$, and IL-10 at the end of the prevention phase. Different letters show significant difference at $\mathrm{P}<0$.
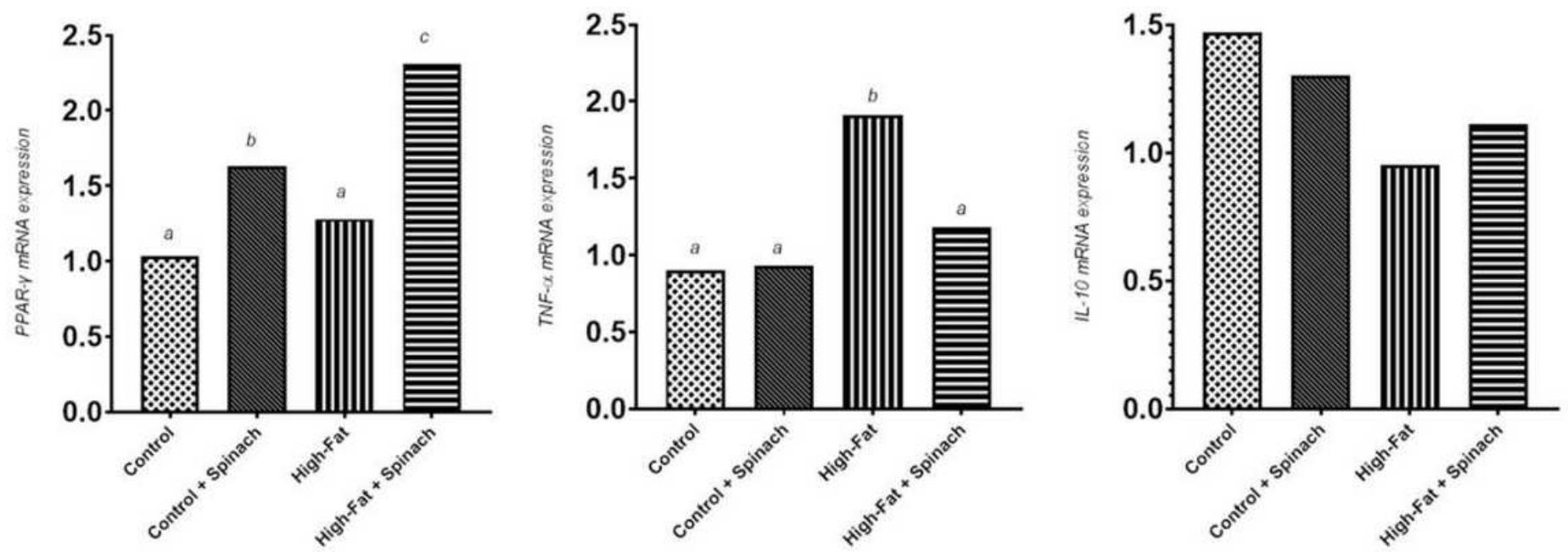

Figure 2

Liver gene expression of PPAR-y, TNF-a, and IL-10 at the end of the treatment phase. Different letters show significantly different at $\mathrm{P}<0.05$. 
This is a list of supplementary files associated with this preprint. Click to download.

- supplementary.rar 